\title{
The Role of Quality of Goods in Formation of Consumer Choice
}

\author{
Bagautdinova N.G. ${ }^{a}$ \\ Safiullin L.N. ${ }^{b}$ \\ Mubarakov I.A.c1 \\ abc Kazan Federal University, Kazan, 420008, Russia \\ 'Email address: verkbund@gmail.com
}

\section{Doi:10.5901/mjss.2014.v5n12p63}

\begin{abstract}
The article presents theoretical-methodological approach to the content of consumer behavior taking into account quality of goods that allowed to formulate practical recommendations concerning methods of its regulation in conditions of modern Russian economy. It offers methodical approach to determination of quality as basic factor of consumer behavior, based on assessment of integrated criterion of quality as the radius vector of the $n$-dimensional space characterizing set of uniform characteristics of quality for various categories of a product consumers, work or service number of measurements of which is defined by the structure of consumer community for this product on the basis of which the vector of consumer usefulness of production by criterion of quality is formed.
\end{abstract}

Keywords: consumer behavior, consumer demand, quality of consumer goods, consumer choice, Russian economy, state regulation, institutes of the market of consumer goods.

\section{Introduction}

The beginning of the XXI century marked a transition to the new era which is characterized by formation of new postindustrial economic way, increase of a role of a human capital in formation of cumulative income, processes of network development and common economic space globalization. All this predetermines need of reconsideration of conceptual provisions of modern economic science, formation of the new methodological approaches, allowing to explain the new phenomena and processes, to predict tendencies of their development taking into account changes of ontologic and gnoseological character. One of problems of the modern economic science demanding deep reconsideration, is the problem of quality which from the local concept reflecting separate attributive signs of this economic event, presented by set of signs, properties and features, turns into the category of higher order characterizing system of sets of uniform (similar) elements in a long-term time interval and in spatial measurement $[1,3]$.

Thereby, the independent problem of quality of private goods and services is transformed to an isolated case of a common problem of quality of life which is defined by quality of the public and private benefits, quality of system of providing national and economic security, quality of transaction in the markets of factors of production and final goods, quality of the relations with participation of the states and supranational formations, etc. Quality represents category which reflects a condition of the social and economic relations on micro, meso, macro and mega-levels, acts as the attributive characteristic of goods, services and processes, defines level of competitiveness of a separate product, economic operators and state as a whole. In this regard formation of complete concept within which quality will carry out a key role, has theoretical and practical importance that defined a choice of a subject of research.

\section{Methodology}

The beginning to philosophical judgment of quality as identical definiteness with life was put by G. W. F. Hegel. Quality as non price factor of consumer demand was traditionally investigated in works of representatives of neoclassical tradition, among which - E. von Bem-Bawerk, L.Valras, F. von Wieser, W.St Javons., J. B. Clark, A.Marshall, K.Menger, F. Edgeworth, etc.

The understanding of need of formation of control system of quality led to formation of schools of sciences in this field, presented by school of scientific management (F. U. Taylor, A.Fayol, etc.), behavioral schools (A.H.Maslow, D. 
Mac-Gregor, etc.), system approaches (L.Fon Bertalanfi, etc.), the concept of general quality management (U.E.Deming, J. Dzhuran, K.Ishikawa, F. Crosby, G. Taguchi, etc.), the concept of "six sigma of quality" (B. Smith).

At the same time, the critical analysis of the specified works $[2 ; 5 ; 6 ; 9 ; 10]$ shows that research of quality of goods and processes is conducted mainly in context of applied problems of management by economic operators. Thus there are no conceptual approaches to treatment of a problem of quality taking into account features of a post-industrial stage of development of human civilization. All this defined a choice of the purpose and research problems, and also its structure.

Theoretical and methodological basis of research is as follows: fundamental ideas of the theory of consumer behavior, the theory of functional and nonfunctional demand, the theory of contracts and transactional expenses, theories of behavioral economy, the theory of institutes and institutional changes, theories of the branch markets, quality management theories, etc. $[3 ; 4 ; 7 ; 11]$.

Quality of consumer goods is interpreted as axiological - standard category, as set of patrimonial and specific properties, signs and features the set of which makes consumer value. Depending on what requirements the goods allocated with these qualities satisfies, economic, social, environmental benefits are allocated. Axiological - standard nature of category of quality is defined by that the economic agent making a consumer choice, acts in conditions of incompleteness of information which for it takes the form of information asymmetry. According to paradox Allais, the real agent sees rationality in behavior of achievement of absolute reliability/reliability, instead of in obtaining the maximum expected usefulness. It demands correction of principles of theory of ordinal utility acting as initial at treatment of consumer behavior taking into account time span, accessory to certain social level, age, psychological, gender, religious, cross-cultural, etc. features of the economic agent.

Quality is defined as relative concept that assumes need of its assessment for comparison to standard indicators or with indicators of quality of uniform and (or) identical goods. In this regard use of two groups of indicators of quality of goods - absolute and relative is obviously necessary. Absolute measures of quality of goods are among the usefulness treated as medical category; reliability of goods of long consumption (durability, non-failure operation); the technological effectiveness characterizing efficiency of design and technological decisions (labor input, power consumption); esthetics of products. Units of measure in each separate case are adapted for these goods.

Relative units of measure include the specific weight of new goods generally its consumption; specific weight of the lowest, normal and the highest goods in total amount of a consumer basket; specific weight of the certified, licensed goods, and also the goods acquired in legal market in total amount of a consumer basket and in total amount of uniform and identical goods; specific weight of the goods conforming to the international standards of quality in total amount of a consumer basket and in total amount of uniform and identical goods; specific weight of import goods in total amount of a consumer basket and in total amount of uniform and identical goods, etc. It is obviously possible to use indirect indicators, as the sum of losses of the consumer (in terms of money) or the missed benefit connected with acquisition of low-quality production. Thus, the data set of indicators reflects various aspects of quality, as set of parametrical, operational, consumer, technological, design properties of goods of personal consumption, and also level of their standardization, unification, reliability and durability.

As a method of research of the factors defining quality of private goods, there was used the focus group method for constant consumers and a method of deep interviews with experts of branch (on the example of the tea market as foodstuff and the market of cell phones as nonfood goods). The conducted research showed that quality of consumer goods acts as objective and subjective category, functional and which nonfunctional components are formed under the influence of a number of factors (table 1 ).

Table 1: Factors of formation and components of quality of consumer goods

\begin{tabular}{|c|c|c|}
\hline & Factors of formation of quality & Elements of quality \\
\hline \multirow{5}{*}{ 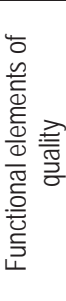 } & Licensing, certification, standardization, metrological control & \multirow{2}{*}{ Safety of use } \\
\hline & Counterfeit protection (hologram, packing, etc.), sale place & \\
\hline & $\begin{array}{l}\text { The country of origin (the food made in Russia, are perceived as natural, the } \\
\text { goods made in Western Europe as more better, than in Eastern Europe, the } \\
\text { goods made in the countries of South East Asia as less qualitative, than in } \\
\text { Western Europe, etc.) }\end{array}$ & \multirow[t]{2}{*}{$\begin{array}{l}\text { High-quality ingredients without artificial } \\
\text { additives (for consumer goods of food } \\
\text { group), balance of the price and quality }\end{array}$} \\
\hline & premium pricing & \\
\hline & Popularity of the trademark (service mark), country of origin, business reputation & $\begin{array}{l}\text { Reliability and duration of effect (for } \\
\text { consumer goods of nonfood group) }\end{array}$ \\
\hline
\end{tabular}




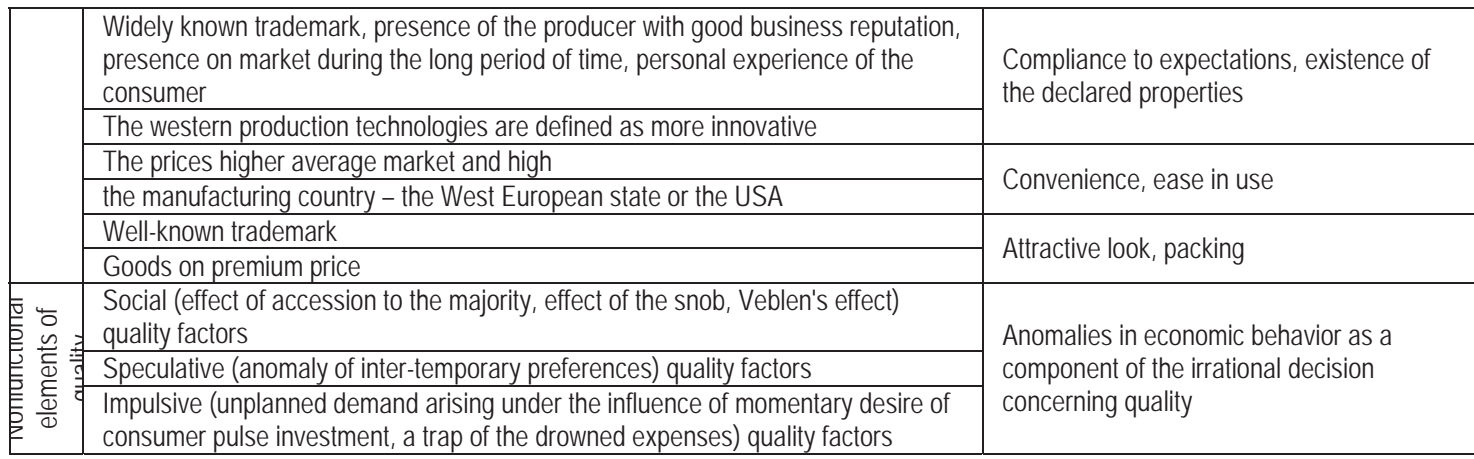

During the phases of life cycle of goods extent of influence of listed factors in formation of quality changes, namely: at an origin stage the greatest role in formation of the loyal consumer is carried out by the subjective factors forming functional components of quality, among which well-known trademark, a premium price. At the subsequent stages the key role in formation of components of quality is carried out by other (objective) factors. Anomalies in economic behavior have impact on formation of nonfunctional components of quality at all stages of life cycle of goods $[9,13]$. During research distinctions in extent of influence of various factors of formation of quality for consumers of various age groups are revealed (for consumers aged up to 25 as a decisive factor acts popularity of the trademark (service mark), the country of origin, business reputation; for senior consumers aged from 26 up to 50 years - licensing, certification, standardization, metrological control; for consumers up to 50 years - the manufacturing country, influencing a ratio of the price and quality).

\section{Conclusion}

The conducted research didn't reveal essential distinctions in models of perception of quality of consumers and producers that is caused by aspiration of the last to overcome a gap between expectations of consumers and their perception of quality of goods within development and realization of competitive strategy. At the same time the treatment of quality as the combined objective and subjective category formed with participation of the producer (seller) and buyer (consumer) allows to consider an objective component as result of functioning of the enterprise organizations whereas the subjective component is formed by the consumer under the influence of rational and irrational expectations. In this regard the treatment of the contract relations with participation of the producer and the consumer as inconsistent relations concerning quality of consumer goods as the conscious value, taking various form is obviously possible.

Presented in fig. 1 matrix reflecting forms of this contradiction, is made with use of approach of G. Simon.

\begin{tabular}{|l|l|l|l|}
\hline \multicolumn{2}{|c|}{ The objective component of quality formed by the producer } \\
\hline & \multicolumn{1}{|c|}{ high } \\
\hline
\end{tabular}

Fig.1. Forms of resolution of conflicts between objective and subjective quality components of consumer goods

Research shows that in total amount of a consumer demand the greatest specific weight occupies demand for the consumer goods, being characterized with average quality. This regularity acts as a form of realization of two regularities - adverse selection and a scale effect that finds reflection in character of the competitive structures presented by mainly monopolistic competition and an oligopoly [14]. Thus, the conducted research showed that quality of consumer goods acts as one of the factors defining type of market structures and forms of the competition in the branch markets.

Carried-out analysis of essence and characteristics of quality as the factor substantially defining behavior of 
consumers, showed that this independent variable in modern conditions can't be considered as the determined indicator presented by quality within the majority of researches that is caused by a difference in perception of a level of quality of goods, works and services by various categories of consumer

Thereof at research of a phenomenon of quality as the basic factor defining consumer behavior, it is necessary to consider this parameter as the radius vector of $n$-dimensional space (characterizing set of uniform characteristics of quality for various categories of consumers of a product, work or service) which number of measurements is defined by structure of consumer community for this product that can be formalized as follows:

$\mathrm{Q}=(\mathrm{q} 1, \mathrm{q} 2, \ldots, \mathrm{qn})(1)$

where $\mathrm{Q}-\mathrm{a}$ resultant vector of quality of production, works or services, characterizing set of uniform characteristics of quality for each of types of consumers (dimension of space of consumers $-1 \div n$ );

$q 1,2, \ldots, n-$ the characteristic of quality of production, works or services for each of types of consumers.

Thus, at quality research within three-dimensional consumer space (for example, an assessment of quality of goods by consumers - the enterprises of private form of ownership of qpe, the state form of ownership of qse, the mixed form of ownership of qpse), the vector of quality of $Q$ within this space will have the following appearance (fig. 2).

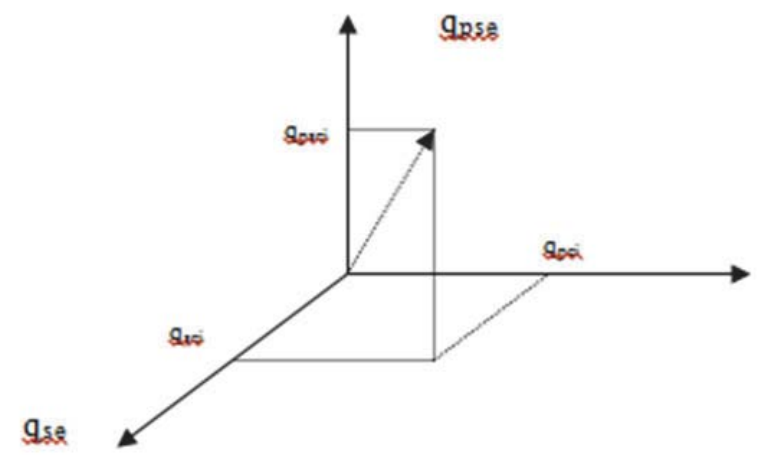

Fig.2. Positioning of a three-dimensional vector of quality of goods in consumer space of the enterprises of various forms of ownership

Formation quality radius vector in consumer space with other dimension is realized similarly, taking into account need of observance of parity of dimension of vector and dimension of consumer space.

Usefulness of acquired product, works or services for consumers, respectively, is considered on quality factor for separate categories of consumers and also represents usefulness radius vector that can be formalized as follows:

$\mathrm{Uq}=(\mathrm{uq} 1, \mathrm{uq} 2, \ldots, \mathrm{uqn})(1)$

where $U q-a$ resultant vector of usefulness of production, works or the services, characterizing set of uniform characteristics of usefulness for each of types of consumers taking into account a level of quality estimated by them;

u q1, q2, ..., qn - the characteristic of consumer usefulness of i-that type of production, works or services for i-that type of the consumers, determined by a quality factor.

This circumstance dictates need of use of instruments of vector algebra in the analysis and modeling of characteristics of quality and the usefulness, characterizing the consumer value of production.

For determination of dependence of consumer behavior (defined through production utility level for consumers) from a level of quality of acquired goods (works, services), at the first stage there was carried out convolution of the received vectors of quality and usefulness to the uniform determined value for each category of analyzed production which was made by means of calculation of the average size of uniform characteristics of quality and usefulness for each of types of consumers within which specific weight were shares of the corresponding categories of consumers in their general set. By results of the carried-out convolution the analysis of dependence of consumer usefulness as integrated characteristic of consumer demand from integrated level of quality of considered goods.

Apparently from the provided data, studied dependence is rather strong (which is characterized by high value of coefficient of determination of R2 $=0,8091$ ) within the studied selection containing 25 elements, and represents logarithmic dependence which can be formalized for this selection as follows:

$\mathrm{U}=57,136 \ln$ (Qint) $+87,186(3)$ 
where $U$ - integrated usefulness of goods, works or services for studied set of consumers, utils;

Qint - an integrated assessment of quality of goods, works or services for studied set of consumers, point $(0 \div 7: 0$ - quality is estimated by consumers as very low, 7 - quality is estimated by consumers as very high).

Application of this technique allows to predict consumer usefulness of production, works or services depending on level of their quality that, in turn, assumes possibility of definition of dynamics of consumer behavior on prospect. Carriedout calculations illustrate a role of quality in formation of consumer expenses that is a starting position for formation of theoretical-methodical justification of measures of the state impact on consumer expenses for the purpose of their transformation in effective demand as a source of forward macroeconomic dynamics.

\section{References}

Lancaster K. A New Approach to Consumer Theory // Journal of Political Economy. Apr. 1966.

Lavoie M. A Post Keynesian Approach to Consumer Choice // Journal of Post Keynesian Economics. -1994. V. 16. - № 4. - P. 539-563.

Lerman, R., Yitzhaki S. (1985) Income Inequality Effects by Income Source: A New Approach and Applications to the United States, The Review of Economics and Statistics, Vol. 67 (1), pp. 151-156.

Askhatova L.I., Bulnina I.S. Quality-of-life (QOL) improvement as a strategic resource of sustainable social and economic development of a region. Life Science Journal $2014 ;$ 11(6s): 354-357.

Glebova I.S., Sadyrtdinov R. and Rodnyansky D. Impact Analysis of Investment Attractiveness of the Republic of Tatarstan on Fixed Investments of its Leading Companies // World Applied Sciences Journal 26 (7): 911-916, 2013.

Fakhrutdinova, E., Safina, L., Kolesnikova, J., Fedor, Mikhailov. Quality formation of working life of the youth// World Applied Sciences Journal. Volume 27, Issue 13, 2013, Pages 87-91.

Miller M.S. Methodology and the Theory of Consumer Behavior // Review of Social Economy. 1983. - № 41. - P. 39-51.

Morduch, J. (1995). Income smoothing and consumption smoothing, Journal of EconomicPerspectives, 9 (Summer), pp. 103-114.

Kirshin I.A., Datsyk A.A., Titov A.V. Forecasting the Dynamics of an Innovative Cycle. - World Applied Sciences Journal (Economics, Management and Finance). - 2013. - №27. - P. 197 - 201.

Skoufias E. (2003) Consumption smoothing in Russia: Evidence from the RLMS// Economics of Transition, Vol. 11, pp. 67-91.

Wooldridge, J. M. Econometric Analysis of Cross Section and Panel Data. Cambridge, Massachusetts: The MIT Press. 2002.

Varlamova J.A., Larionova N.I. Economic behavior of households: cross-country comparison. Life Science Journal 2014; 11(6s): 409413.

Yitzhaki S. 2002. Do we need a separate poverty measurement?// European Journal of Political Economy, Vol. 18, 61-85.

Zhang, R. Ramakrishnan, and M. Livny, Birch: An Efficient Data Clustering Method for Large Databases, Proc. ACM SIGMOD Int'I Conf. Management of Data, ACM Press, New York, 1996, pp. 103-114. 
